Li, J.S., Xu, H., \& Chen, S.S. (2012). The effect of flow and motivation on users' learning outcomes in Second Life. Journal of Educational Technology Development and Exchange, 5(1), 95-108.

\title{
The Effect of Flow and Motivation on Users' Learning Outcomes in Second Life
}

\author{
Jian-Sheng Li \\ Huan Xu \\ Si-Si Chen \\ Nanjing Normal University
}

\begin{abstract}
This study aims to investigate the effect of the users' immersion experience, motivation, and learning outcomes in Second Life. The data collected for this study occurred over a 2 month period. Participants were 113 students taking classes in Second Life at a university. Their ages ranged from 18-22 years, with 47 participants as male and 66 as female. From the analysis of the collected data, the immersion experience and motivation have effects on the learning outcomes in Second Life. The results revealed one more was immersed in Second Life, the motivation was improved, and thus, the learning outcomes were reinforced. These findings are also discussed in virtual learning and teaching design.
\end{abstract}

Keywords: flow, game motivation, learning outcomes, Second Life

\section{Introduction}

Second Life is an online virtual world, which provides interaction in a variety ways through text and audio-visuals. In this world, users are called "Residents" and are characterized as avatars. Similar to the real world, "Residents" can take part in one or more communities to achieve the sense of immersion and belonging. Additionally, there is also a procedural scripting language, Linden Scripting Language, which can be used to add activities to newly-built objects and create more complex systems. The use of Linden Scripting Language is the extension of interaction between the virtual and the real. The design that is closer to real situations and simulated experiences makes it easier for users to immerse in Second Life.
Immersion, according to the Flow theory from psychologist Mihaly Csikszentmihalyi (1975), occurs when people are doing some daily activities where they are fully immersed. Their attention is drawn to the situation, as they filter out all irrelevant perceptions.

It was found that flow state and performance are positively related in some fields such as chess, sports, visual arts, and so on (Csikszentmihalyi, 1990). Additionally, Sedig (2007) proposes an operating model of immersion experience that is the core such as children taking mathematics learning in an integrated manner. The results show that the model is efficient for the improvement of children's understanding of mathematics. LiAn Ho (2010) investigated the relationship among the attitude of computer usage of the 
senior technical staff, immersion experience, and learning outcomes. They collected 239 samples from 50 technology companies in Taiwan and found that the attitude of using computer and immersion experience have positive impacts on online learning outcomes.

However, the above studies have been done in regular daily life. So, the question is whether the same results occur in the virtual world? Therefore, the goal of this study was to examine the users' flow state and performance in the virtual world. In this research, the virtual world is referred to Second Life and the learning outcomes are referred to as the perceived academic self-efficacy. Thus, the users' immersion, motivation, and perceived academic self-efficacy are explored in Second Life.

\section{Theoretical Background}

\subsection{Flow}

Flow is the mental state of operation in which a person in an activity is fully immersed in a feeling of energized focus, full involvement, and feelings of success in the process of the activity. Csikszentimihalyi (1990) thought that the key to achieving the flow state was whether the challenges and skills were balanced. When individuals' skills and the challenges of activities are balanced, individuals can reach the state of flow. But, on the basis of large quantities of research in sports psychology, Kimiecke and Stein (1992) concluded that flow experience was not the result of a single factor, but the product of the interaction between the structure of activities and personal abilities. So, they put forward the individual and situational flow model on top of the theory of Csikszentmialyi. In this model, personal influential factors concerned with the flow state include individual characteristics variables such as goal orientation and specific anxiety, and individual state variables such as goals, attention, and self-efficacy.
Sweetser (2005) offered the game flow factors as: focused attention, explicit goals, timely feedback, loss of self-consciousness, integration of activities and awareness, balance of challenge and skill, distortion of time and perception, and heartfelt to participate in activities. As for the flow's measure, the questionnaire method is used most. Researchers set many flow scales from different dimensions (see Table 1 on next page).

In this paper, we refer to the Sweetser's theory of Game Flow to design the questionnaire to measure the students who are learning in Second Life.

\subsection{Motivation}

Motivation is the direct reason to cause, inspire, and sustain some sort of human behavior. Bartle has performed a lot of research in this area. According to the Bartle's theory of users' motivation model (2004), the users are divided into three types: achievement, social, and immersion. The achievement users mostly play games to accumulate virtual wealth, improve equipment level, and have a much better virtual character whose level skills are superior to the other players. The social users are more likely to enjoy rich social life in online games. They are happy to know other players who are kindred in games. The immersion users play games to avoid and forget real-life troubles and displeasures. They play games to distract and avoid loneliness. The three different types of motivation are not exclusive; the same users may have one or more of these three motivations, but the different motivations' users have related to different tendencies.

Based on the Bartle's theoretical model, the questionnaire investigating users' motivation was designed for examining the achievement, social, and immersion dimensions in this paper. 
Table 1. Different Dimensions of Flow Scale

\begin{tabular}{|c|c|c|}
\hline First Author & Year & The Elements of Flow \\
\hline Sweetser & 2005 & $\begin{array}{l}\text { focused attention, explicit goals, timely feedbacks, loss of self- } \\
\text { consciousness, integration of activities and awareness, balance of } \\
\text { challenge and skill, distortion of time and perception, heartfelt to } \\
\text { participate in activities. }\end{array}$ \\
\hline Trevino & 1992 & sense of control, concentration, curiosity, interest. \\
\hline Hoffman & 1996 & $\begin{array}{l}\text { skill/control, challenge/awakening, concentration, interaction, } \\
\text { situational sense in long-distance. }\end{array}$ \\
\hline Hoffman & 1997 & $\begin{array}{l}\text { timely feedback, pleasure, the loss of self-consciousness, self- } \\
\text { reinforcing. }\end{array}$ \\
\hline Agarwal & 2000 & sense of control, concentration, curiosity, interest. \\
\hline Li-An Ho & 2010 & Autonomy, concentration, stimulation, motivation. \\
\hline Fang Ma & 2010 & $\begin{array}{l}\text { balance of skill and challenge, effortless concentration, sense of } \\
\text { time change, clear goal, spontaneous experience, loss of self- } \\
\text { consciousness, sense of control. }\end{array}$ \\
\hline FongLing $\mathrm{Fu}$ & 2009 & $\begin{array}{l}\text { Concentration, clear goals, feedback, challenge, sense of control, } \\
\text { sense of involvement, social interaction, knowledge learning. }\end{array}$ \\
\hline
\end{tabular}

\subsection{Learning Outcomes}

Perceived academic self-efficacy refers to individuals' convictions that they can successfully perform given academic tasks at designated levels (Schunk, 1991). It is a subjective judgment of individuals to control their own learning behaviors and achievement. Self-efficacy researchers stress the cognitive nature of academic self-efficacy beliefs. Individual learning effort, the attitude towards challenging tasks, the persistence of learning, the use of learning strategies, and meta-cognitive strategies are composition of perceived academic self-efficacy. Researchers think the perceived academic self-efficacy is divided into two dimensions. Basic efficacy, which is the subjective feeling of students to evaluate talents, mainly includes: conviction of good learning results, the sense of accomplishment of reaching learning goals, the talent of learning, positive self-expected, and self-confidence. The second dimension of sense of control, which is the sense of control of learning tasks and subjective judgment of control of learning behavior mainly includes: self-doubting, the sense of interference, the sense of adverse environment, the sense of powerlessness, and the sense of effort. Summing the above, Table 2 shows the different dimensions of perceived academic self-efficacy scale. 
Table 2. Different Dimensions of Perceived Academic Self-efficacy Scale

\begin{tabular}{ccl}
\hline First Author & Year & \\
\hline Bandura & 1991 & $\begin{array}{l}\text { Defining efficacy with the sense of ability. } \\
\text { Schwarzer }\end{array}$ \\
1999 & $\begin{array}{l}\text { Subject should be me, which is aimed to measure the individual's } \\
\text { subjective belief; it should include the verb of can or be able to, to } \\
\text { make sure that success is based on capability; it should include barriers } \\
\text { or some challenging tasks to make it harder. }\end{array}$ \\
Yufang Bian 2004 & $\begin{array}{l}\text { The elements include the effort and capability of individuals themselves } \\
\text { and the sense of environment as well as the control of behaviors. }\end{array}$ \\
\hline
\end{tabular}

In this paper, we survey the learning outcomes in the form of perceived academic self-efficacy on the basic theory of Yufang Bian (2004).

\section{Research Model}

Based on the theoretical background presented above, a theoretical model of the relationships among flow, game motivation, and learning outcomes were articulated. The flow was classified into eight dimensions in this study: game motivation into three dimensions and learning outcomes as perceived academic self-efficacy. According to the collected data, it assumed that the flow experience and game motivation had effects on the perceived academic self-efficacy. Figure 1 displays our research structure. Specific hypotheses are as follows:

Hypothesis 1: The flow experience has relation to the perceived academic self-efficacy.

Hypothesis 2: The motivation has relation to the perceived academic self-efficacy.

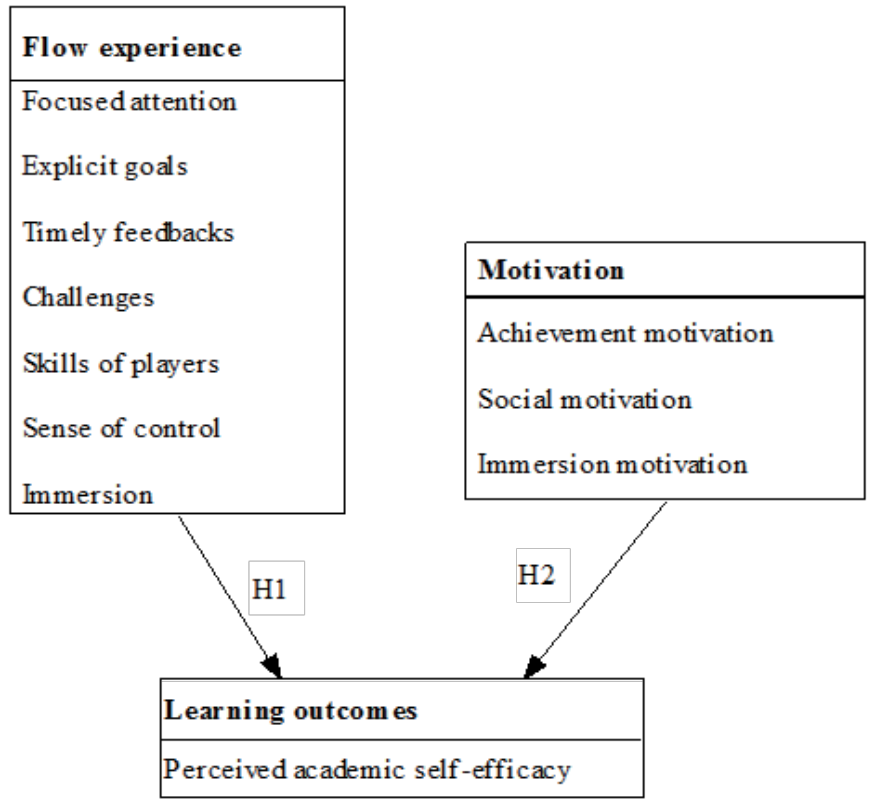

Figure 1. Research structure 


\section{Method}

\subsection{Sample}

Subjects were 113 students coming from Nanjing Normal University, who have already taken classes in Second Life. Their ages ranged from 18-22 $(M=27.863 ; S D=5.798)$, and $47(42 \%)$ of these subjects were male, with $66(58 \%)$ being female.

\subsection{Material}

Based on the Sweetser's (2005) Game Flow theory, flow state scale is set on seven dimensions to test the user's flow experience. The seven factors are: focused attention, explicit goals, timely feedback, challenges, skill of players, the sense of control, immersion, and interaction (see Appendix1).

Motivation scale is formed by the Bartle's theory presented above. We set three different dimensions of game motivation experience to examine the game motivation in Second Life (see Appendix 2).
As for the users' learning-outcomes, we set two basic dimensions of several questions to evaluate the perceived academic self-efficacy in Second Life, which based from the theory of Yufang Bian (2004) (see Appendix 3).

The scales' reliability and validity are seen in Table 3 and Table 4.

Usually, the Cronbach's alpha coefficient is used to test the questionnaire's reliability. When the Cronbach's alpha coefficient is above 0.6 , the questionnaire is considered more credible. The Cronbach's Alpha of our questionnaire is around 0.537 which shows the reliability being acceptable (see Table 3 ).

While KMO statistic is used to test the questionnaire's validity and the value is set between 0 and 1 . Usually, the value above 0.9 is very suitable, 0.8 is suitable, 0.7 indicates a general, 0.6 is not suitable, and anything below 0.5 is not suitable. According to Table 4 , the value of our questionnaire's KMO and Bartlett's test is 0.703 . The result shows that the questionnaire validity is suitable.

Table 3. Questionnaire Reliability

\begin{tabular}{cc}
\hline \multicolumn{2}{c}{ Reliability statistics } \\
\hline Cronbach's Alpha & The number of items \\
.537 & 4 \\
\hline
\end{tabular}

Table 4. Questionnaire Validity

\begin{tabular}{lcc}
\hline \multicolumn{3}{c}{ KMO and Bartlett's test } \\
\hline Kaiser-Meyer-Olkin measure of sampling sufficient degree & .703 \\
\hline \multirow{2}{*}{ Bartlett's sphericity test } & Approximate chi-square & 4.265 \\
& $d f$ & 6 \\
& Sig. & .641 \\
\hline
\end{tabular}




\subsection{Procedure}

A within-subjects design is an experiment in which the same group of subjects serves in more than one treatment. There are two fundamental advantages of the within subjects design: (1) power and (2) reduction in error variance associated with individual differences.

In this paper, we employed the withinsubjects design because we only have 113 subjects in this experiment. By using a within-subjects design, we have in effect increased the number of "subjects" relative to a between-subjects design. With the withinsubjects design, conditions are always exactly equivalent with respect to individual difference variables because the participants are on the same level in different conditions. So, in our experiment, any factor that may affect learning-outcomes on the dependent variable such as flow experience or game motivation will be exactly the same for the two conditions, because the sample is the exact same group of people in the two conditions.
Thus, all participants were treated in the three different tests, including flow experience, game motivation, and self-efficacy. The test instruments are the above scales that are set at five different levels: "fully agree" referred to the mark of 5, "relatively agree" referred to the mark of 4, "not clear" referred to the mark of 3, "relatively disagree" referred to the mark of 2 , and "fully disagree" referred to the mark of 1. Each participant's responses are then calculated and analyzed after data collection. The data was processed with excel 2010 software and the SPSS 18.0 software.

\section{Results}

\subsection{The Flow Experience in Second Life (SL)}

Questionnaire was carried out to measure the users' flow experience in Second Life. To research the users' flow experience, quantitative items focused on users' attention, skill, sense of control, timely feedback, and loss of self-consciousness. Items used for quantitative analysis were on a 5-point Likertscale. Table 5 shows the questionnaire items and response options.

Table 5. Questionnaire of the Flow Experience

\begin{tabular}{lccccc}
\hline \multicolumn{1}{c}{ Options } & $\begin{array}{c}\text { Fully } \\
\text { agree }\end{array}$ & $\begin{array}{c}\text { Relatively } \\
\text { agree }\end{array}$ & $\begin{array}{c}\text { Not } \\
\text { clear }\end{array}$ & $\begin{array}{c}\text { Relatively } \\
\text { disagree }\end{array}$ & $\begin{array}{c}\text { Fully } \\
\text { disagree }\end{array}$ \\
\hline $\begin{array}{l}\text { 1. SL attracts my attention. } \\
\text { 2. The difficulty of SL is right for me. }\end{array}$ & 26 & 41 & 24 & 11 & 9 \\
$\begin{array}{l}\text { 3. I am familiar with operating SL } \\
\text { skills. (Like Keyboard skills). }\end{array}$ & 25 & 39 & 28 & 16 & 5 \\
$\begin{array}{l}\text { 4. I feel SL is under my control. } \\
\begin{array}{l}\text { 5. SL provides me with timely } \\
\text { feedback. }\end{array}\end{array}$ & 27 & 44 & 27 & 15 & 0 \\
$\begin{array}{l}\text { 6. I know exactly what I will do in SL. } \\
\text { 7. I do not feel the elapse of time }\end{array}$ & 22 & 39 & 26 & 14 & 14 \\
$\quad \begin{array}{l}\text { while playing SL. } \\
\text { 8. SL provides appropriate messages } \\
\text { to complete the tasks. }\end{array}$ & 25 & 35 & 29 & 20 & 11 \\
\hline
\end{tabular}


From Table 5, we can see the following information: (a) the content, the level of difficulty, and the skillful skills are important to a user. Only when the skills and challenges are appropriate to the students, can their immersion experience be improved; (b) Second life offers immediate feedback and useful information to help users, which make users take the classes under control and forget the time flowing; and (c) most of the students are immersed in Second Life while only a small part of them do not have a pleasant experience in Second Life. Those feeling sad about Second Life think that the operating skills are hard to be mastered.

\subsection{The Users'Motivation in Second Life (SL)}

Based on the theory of Bartle, the users' motivation was divided into three dimensions and in each dimension had two questions to examine the motivations in Second Life, and items used for quantitative analysis were on a 5-point Likert scale (see Table 6).

Table 6. Questionnaire of the Users' Motivation

\begin{tabular}{lccccc}
\hline \multicolumn{1}{c}{ Options } & $\begin{array}{c}\text { Fully } \\
\text { agree }\end{array}$ & $\begin{array}{c}\text { Relatively } \\
\text { agree }\end{array}$ & $\begin{array}{c}\text { Not } \\
\text { clear }\end{array}$ & $\begin{array}{c}\text { Relatively } \\
\text { disagree }\end{array}$ & $\begin{array}{c}\text { Fully } \\
\text { disagree }\end{array}$ \\
\hline $\begin{array}{l}\text { 1. Finishing objectives of characters as } \\
\text { soon as possible is important for me. }\end{array}$ & 34 & 47 & 19 & 13 & 0 \\
$\begin{array}{l}\text { 2. Becoming famous in the game is } \\
\text { important for me. }\end{array}$ & 29 & 37 & 26 & 12 & 9 \\
$\begin{array}{l}\text { 3. I prefer to chat with other players to } \\
\text { have meaningful conversations. }\end{array}$ & 33 & 43 & 20 & 16 & 1 \\
$\begin{array}{l}\text { 4. I like to identify problems that others } \\
\text { did not pay attention to. }\end{array}$ & 21 & 36 & 35 & 19 & 2 \\
$\begin{array}{l}\text { 5. I often play games to forget problems } \\
\text { and troubles in reality. }\end{array}$ & 24 & 29 & 34 & 17 & 9 \\
$\begin{array}{l}\text { 6. I often play games to escape from the } \\
\text { reality of life }\end{array}$ & 13 & 20 & 33 & 23 & 24 \\
\hline
\end{tabular}

From Table 6, we can see the following results: (a) the motivation includes some essential parts such as finishing the mission quickly, having meaningful conversations with others, and so on. These factors are much more important for students to have classes in Second Life, and the sociality of Second Life makes students feel motivated; (b) most users play in Second Life have a good motivation and think it is a platform to learn; and (c) the majority of the users' motivation is achievement motivation rather than for emotional purposes.

\subsection{The Perceived Academic Self-efficacy in Second Life (SL)}

The perceived academic self-efficacy is examined under two basic dimensions: the basic sense of ability and the sense of control. We established 10 questions to examine the perceived academic self-efficacy, and items used for quantitative analysis were on a 5-point Likertscale (see Table 7). 
Table 7. Perceived Academic Self-efficacy in SL

\begin{tabular}{|c|c|c|c|c|c|}
\hline Options & $\begin{array}{l}\text { Fully } \\
\text { agree }\end{array}$ & $\begin{array}{l}\text { Relatively } \\
\text { agree }\end{array}$ & $\begin{array}{l}\text { Not } \\
\text { clear }\end{array}$ & $\begin{array}{l}\text { Relatively } \\
\text { disagree }\end{array}$ & $\begin{array}{l}\text { Fully } \\
\text { disagree }\end{array}$ \\
\hline $\begin{array}{l}\text { 1. The learning in SL can improve } \\
\text { my efficiency. }\end{array}$ & 23 & 48 & 29 & 11 & 2 \\
\hline 2. I always get my job done. & 31 & 41 & 20 & 12 & 9 \\
\hline $\begin{array}{l}\text { 3. My learning ability in SL is } \\
\text { superior to others. }\end{array}$ & 34 & 39 & 24 & 14 & 2 \\
\hline $\begin{array}{l}\text { 4. Before learning, I have a good } \\
\text { expectation of learning outcomes. }\end{array}$ & 22 & 32 & 36 & 13 & 10 \\
\hline $\begin{array}{l}\text { 5. Learning in SL is better than } \\
\text { traditional learning. }\end{array}$ & 21 & 44 & 24 & 11 & 13 \\
\hline $\begin{array}{l}\text { 6. I never doubt that whether my } \\
\text { answer is right. }\end{array}$ & 29 & 35 & 37 & 10 & 2 \\
\hline $\begin{array}{l}\text { 7. I always concentrate on learning } \\
\text { in SL. }\end{array}$ & 23 & 32 & 36 & 13 & 9 \\
\hline $\begin{array}{l}\text { 8. I am free from the interference of } \\
\text { environmental factors. }\end{array}$ & 31 & 41 & 22 & 19 & 0 \\
\hline $\begin{array}{l}\text { 9. There is no question that I cannot } \\
\text { answer in SL. }\end{array}$ & 25 & 40 & 20 & 15 & 13 \\
\hline $\begin{array}{l}\text { 10. I tried my best to finish each } \\
\text { goal in SL. }\end{array}$ & 36 & 40 & 23 & 10 & 4 \\
\hline
\end{tabular}

From Table 7 we discovered the following results: (a) most of the participants are immersed in Second Life. Those immersing in learning have a higher perceived academic self-efficacy; (b) accomplishment of the mission accompanies greater motivation of the user to achieve the learning outcome in Second Life; and (c) the majority of the students have confidence in learning in Second Life. Compared to traditional ways, users think it is better to learn course content in Second Life.

\subsection{The Correlation between Flow Experience and Learning Outcomes}

Correlation is a technique for investigating the relationship between two quantitative, continuous variables. Pearson's correlation coefficient (r) is a measure of the strength of the association between the two variables. In order to explore the strength of the association between flow experience and learning outcomes, the Pearson's correlation coefficient was carried out (see Table 8). Pearson correlation of immersion experience and learning outcomes was $=0.577$; P-Value $=0.000$. 
In conclusion, the correlation coefficient indicates that the strength of association between immersion experience and learning outcomes is medium $(r=0.577)$, and that the correlation coefficient is very different from zero $(p<0.001)$. Also, we can say the deeper one is immersed in Second Life, the strengthening effects of perceived academic self-efficacy will be greater. The result shows that the immersion experience of learning is playing a supporting role in strengthening the sense of perceived academic self-efficacy and improving learning outcomes.

Table 8. Correlation between Flow Experience and Learning Outcomes in SL

\begin{tabular}{|c|c|c|c|}
\hline & & Flow & $\begin{array}{c}\text { Perceived academic } \\
\text { self-efficacy }\end{array}$ \\
\hline \multirow[t]{3}{*}{ Flow } & Pearson correlation & 1 & $.577^{* *}$ \\
\hline & Significant (both sides) & & .000 \\
\hline & $\mathrm{N}$ & 113 & 113 \\
\hline
\end{tabular}

**. is significantly associated at the level of .01.

\subsection{The Correlation between Users, Motivation and Learning Outcomes}

For the same principle, in order to explore the correlation between motivation and learning outcomes in Second Life, the Pearson's correlation coefficient was carried out again. The Pearson correlation between learning motivation and learning outcomes is $.550 * *$, which is above the level of $.01^{* *}$. This result indicates a medium positive correlation between learning motivation and learning outcomes. The sense of perceived academic self-efficacy may be strengthened with the reinforcement of the learning motivation. The above results show that increasing learning motivation can help enhance the sense of perceived academic selfefficacy, and then the learning outcomes will be increased (see Table 9).

Table 9. Correlation between Motivation and Learning Outcomes in SL

\begin{tabular}{lccc}
\hline & & $\begin{array}{c}\text { Perceived academic } \\
\text { self-efficacy }\end{array}$ & $\begin{array}{c}\text { Learning } \\
\text { motivation }\end{array}$ \\
\hline $\begin{array}{l}\text { Perceived academic } \\
\text { self-efficacy }\end{array}$ & Pearson correlation & 1 & $.550^{* *}$ \\
& Significant (both sides) & & .000 \\
$\mathrm{~N}$ & 113 & 113 \\
\hline
\end{tabular}

**. is significantly associated at the level of .01. 


\section{Discussion and Conclusion}

According to the hypotheses, the discussions were presented as the following:

(1) This study assumed the users' flow experience and learning outcomes had a positive correlation. From Table 8 and Table 9, the Pearson correlation is $.577^{* *}$, thus hypothesis $\mathrm{H} 1$ is medium supported and so does hypothesis $\mathrm{H} 2$ because the Pearson correlation between learning motivation and learning outcomes is $.550 * *$.

(2) As mentioned above, the correlation coefficient ( $p$-value $=0.000)$ between flow experience and learning outcomes is significant and so does between game motivation and learning outcomes. This is true with the users' attention, goals, skills, and sense of control effect on the learning outcomes. Similarly, the users' achievement motivation, social motivation, and immersion motivation also affect the learning outcomes. On the other hand, the exercises' timely feedback, difficult challenges, and interaction modes are the important factors in virtual learning.

Therefore, in the virtual learning, the users' traits are very important. In the virtual teaching and instructional design world, users' learning characteristics should be given more attention. In the learning resources design area, users' feedback, challenge levels, and interaction modes are given special attention.

But, due to the limitation of the equipment condition, the study of learning effects is only limited to the learners' selfevaluation. On the other hand, the withinsubjects' design employed in this experiment has also disadvantages, that can be referred to as "carryover effects." In general, this means the participation in one condition may affect performance in other conditions, thus creating a confounding extraneous variable that varies with the independent variable. All these may lead to the decline in the accuracy of questionnaire analysis and correlation coefficient. Therefore, these topics mentioned above should be considered in the future research and the users' features should be further explored for the future of virtual learning and teaching design.

\section{References}

Agarwal, V., \& Narayan Y. N. (2000). Multiperiod performance persistence analysis of hedge funds. Journal of Financial and Quantitative Analysis, 35(3), 327-342.

Bandura , A.(1991). Human agency: The rhetoric and the reality. American Psychologist, (46), 157 - 162.

Bartle, R. (1996) Hearts, clubs, diamonds, spades: Players who suit MUDs. Journal of MUD Research, (1), 1-4.

Bian, Y .(2004). Learning self-efficacy Scale. Psychological Science, 27(5), 1218 1222.

Cao, X. , Liu, X.,, Jiang, X., \&, Wang, Z. (2007). Recommend the theory of flow of positive psychology. Journal of Gannan Normal University, (4), 25-29.

Csikszentmihalyi, M. (1990). Flow: The psychology of optimal experience. New York : Harper \& Row, 74-75.

FongLing F., RongChang S., \& ShengChin, Y. (2009). EGameFlow: A scale to measure learners enjoyment of e-learning games. Computers \& Education.

Hoffman, D. L., \& Novak, T. P. (1996). Marketing in hypermedia computermediated environments: Conceptual foundations. Journal of Marketing, (60), 50-68.

Kimiecik, J. C., \& Stein G. L. (1992). Examining flow experiences in sport contexts: Conceptual issues and 
methodological concerns. Journal of Applied Sport Psychology, 4(2), 144- 160.

Li-An, H., \& Tsung-Hsien, K.. (2010). How can one amplify the effect of e-learning? An examination of high-tech employees' computer attitude and flow experience. Computers in Human Behavior, (26), 23-31.

Nakamura, J., \& Csikszentmihalyi, M. (2002). The concept of Flow. In C. R. Snyder, S. J. Lopez (Eds.), The handbook of positive psychology. New York: Oxford Press, 89-103.

Schwarzer, R , Mueller J , \& Greenglass, E. (1999). Assessment of general perceived self-efficacy on the internet: data collection in cyberspace. Anxiety, Stress and Copying, 12(3),145-161.

Schunk, D. H. (1991). Self-efficacy and academic motivation. Educational psychologist, 26, 207-231.

Sweetser, W. (2005). Game flow: A model for evaluating player enjoyment in Games. $A C M$ Computers in Entertainment, 3(3), 1-24.
Trevino, L. K., \& Webster, J. (1992). Flow in computer-mediated communication. Communication Research, 19(5), 539-573. Wang, Y., \& Braman, J. (2009). Extending the classroom through Second Life. Journal of Information Systems Education, (2), 235-247.

Zhang, J. (2011). Study on Primary Mathematics Educational Games Design Based on Flow Theory. Jiangnan University Press.

\section{Acknowledgement}

This study was supported by the Ministry of Education of the People's Republic of China (DCA090319), Education Department, Jiangsu Province (09SJB880038). 


\section{Appendix 1}

Flow Experience Scale (Sweetser, 2005)

\begin{tabular}{|c|c|c|}
\hline Variables & The questions to measure & References \\
\hline Focused attention & Q1 The game attracted my attention. & \\
\hline Explicit goals & Q6 I know exactly what I will do in the game. & \\
\hline Timely feedback & Q5 The game provides me with timely feedback. & \\
\hline Challenges & Q2 The difficulty of the game is right for me. & \\
\hline Skills of players & $\begin{array}{l}\text { Q3 I am familiar with operating game skills.(like } \\
\text { Keyboard skills) }\end{array}$ & $\begin{array}{l}\text { Sweetser } \\
(2005)\end{array}$ \\
\hline $\begin{array}{l}\text { The sense of } \\
\text { control }\end{array}$ & Q4 I feel the game is under my control. & \\
\hline Immersion & Q7 I do not feel the elapse of time while playing games. & \\
\hline Interaction & $\begin{array}{l}\text { Q8 The game provides appropriate messages to complete } \\
\text { the game. }\end{array}$ & \\
\hline
\end{tabular}

\section{Appendix 2}

Game Motivation Scale (Bartle, 1996)

\begin{tabular}{lll}
\hline \multicolumn{1}{c}{ Variables } & \multicolumn{1}{c}{ The questions to measure } & References \\
\hline $\begin{array}{l}\text { Achievement } \\
\text { motivation }\end{array}$ & $\begin{array}{l}\text { Q1 Finishing objectives of characters as soon as } \\
\text { possible is important for me. } \\
\text { Q2 Becoming famous in the game is important for me. }\end{array}$ & \\
Social motivation & Q3 I prefer to chat with other players to have \\
& meaningful conversations. & Bartle (2004) \\
& $\begin{array}{l}\text { Q4 I like to identify problems that others do not pay } \\
\text { attention to. }\end{array}$ & \\
Immersion & Q5 I often play games to forget problems and troubles & \\
in reality. & \\
& Q6 I often play games to escape from the reality of life & \\
\hline
\end{tabular}




\section{Appendix 3}

Perceived Academic Self-efficacy Scale (Yufang Bian, 2004)

\begin{tabular}{lll}
\hline Variables & \multicolumn{1}{c}{ The questions to measure } & References \\
\hline $\begin{array}{l}\text { The basic } \\
\text { efficacy }\end{array}$ & Q1 The learning in Second life can improve my efficiency. & \\
& Q2 I always get my job done. \\
& Q4 Before learning, I have a good expectation of learning outcomes. \\
& Q5 Learning in Second Life is better than traditional learning.
\end{tabular}




\section{Contact the Authors}

\section{Jian-Sheng Li}

Nanjing Normal University

Email: jianshengli333@163.com

\section{Huan Xu}

Nanjing Normal University

Email: 411502460@qq.com

\section{Si-Si Chen}

Nanjing Normal University

Email: 444726022@qq.com 